\title{
ПРО МОДЕРНУ ОСВІТУ В РЕЧІ ПОСПОЛИТІЙ - ПОЗНАНСЬКА МОДЕЛЬ ДОБИ ПРОСВІТНИЦТВА
}

\section{М. Форицький}

\begin{abstract}
Форицький М. Про модерну освіту в Речі Посполитій - познанська модель доби Просвітництва. У XVIII ст. в Познані було створено взірцевий освітній осередок, з яким в Центрально-Східній Європі могли конкурувати хіба що найкращі подібні інституції: на теренах Речі Посполитою єдиною такою рівнозначною школою була Віленська академія. В межах познанської освітньої моделі головне місце посідали математика, експериментальна фізика, астрономія й інші модерні науки (в т.ч. геологія і метеорологія). Успіх Познанського єзуїтського колегіуму доби Просвітництва був пов'язаний насамперед із діяльністю такої видатної особистості, як Юзеф Рогалінський. Важливу роль в цьому зв'язку відіграли його чудова освіта, щільні контакти із західноєвропейською наукою і особиста самопожертва до своєї справи в надзвичайно важку добу розділів Речі Посполитої.
\end{abstract}

Ключові слова: Познанський єзуїтський колегіум; Річ Посполита; освітній осередок; модерні науки; Юзеф Рогалінський.

Форыцкий М. О модерном образовании в Речи Посполитой - познанская модель эпохи Просвещения. В XVIII ст. в Познани был создан образцовый центр образования, с которым в Центрально-Восточной Европе могли конкурироваться разве что наилучшие подобные институции: на просторах Речи Посполитой единственной такой равнозначной школой была Виленская академия. В рамках познанской образовательной модели главное место занимали математика, экспериментальная физика, астрономия и другие модерные науки (в т.ч. геология и метеорология). Успех Познанского иезуитского коллегиума эпохи Просвещения был связан в первую очередь с деятельностью такой выдающейся личности как Юзеф Рогалинский. Важную роль в этой связи сыграли его прекрасное образование, тесные контакты с западноевропейской наукой и самопожертвенное отношение к своему делу в чрезвычайно тяжелое время разделов Речи Посполитой.

Ключевые слова: Познанский иезуитский коллегиум; Речь Посполитая; центр образования; модерные науки; Юзеф Рогалинский.

Forycki M. About the Modern Education in the Polish-Lithuanian Commonwealth - the Poznan Educational Model in the Age of Enlightenment. The exemplary educational center in Poznan, which was established in $18^{\text {th }}$ century, has been able to compete with the best such institutes of the Central and Eastern Europe. There was only the single such equivalent school on the territory of the Polish-Lithuanian Commonwealth, that is Vilnius academy. Within the Poznan educational model a main attention was focused on mathematics, experimental physics, astronomy and other modern sciences (including geology and meteorology). The educational success of Poznan Jesuit College in the Age of Enlightenment was primarily the result of intensive activity of such person as Józef Rogaliński. His wonderful education, close contacts with West-European science and the dedicated attitude to his work, which has been carried out during the extremely hard time of Partitions of the Polish-Lithuanian Commonwealth, have played a particularly important role in the increasing of the Poznan Jesuit College's scientific level.

Keywords: Poznan Jesuit College; the Polish-Lithuanian Commonwealth; educational center; modern sciences; Józef Rogaliński.

У XVIII ст. в Познані створюється взірцевий науковий осередок, з яким на теренах Центрально-Східної Європи могли конкурувати лише найкращі подібні інституції. Головний наголос в рамках познанської моделі робився на вивченні математики, експериментальної фізики, астрономії та інших модерних наук (в т. ч. геології і метеорології). Успіхи Познанського єзуїтського колегіуму доби Просвітництва були нерозривно пов'язані із такою непересічною особистістю як Юзеф Рогалінський. I, насамперед, зумовлені його чудовою освітою, тісними контактами із західноєвропейською наукою й відданістю своїй справі у вкрай нелегку добу поділів Речі Посполитої.

«Вік Світла» у великопольській науці, його початки і апогей, припадають на вкрай коротку - як для культурного перелому - добу останніх років панування Августа III. По- 
знанське Просвітництво було нерозривно пов'язане 3 динамічним і сучасним науковим осередком, який постав у місцевому єзуїтському колегіумі на межі 1750-1760-х pp. ${ }^{1}$. У ньому створюється найславетніша в Речі Посполитій астрономічна обсерваторія ${ }^{2}$ і перший у Польщі, добре обладнаний, фізичний кабінет ${ }^{3}$.

Серед чинників, які відіграли ключову роль у появі і динамічному розвитку познанського наукового осередку, на перше місце варто поставити протекцію Марії Лещинської ${ }^{4}$. Саме завдяки дружині Людовіка XV, котра була тісно пов'язана із Товариством Ісуса і рідною Великопольщею, познанські єзуїти в 1750-х рр. отримали можливість навчатися у Франції5. Окрім того, розвиткові познанської науки надали імпульс новаторські реформи шкільництва в Польщі, наслідком яких стала творча конкуренція єзуїтів із піарами

Запорукою успіху стало, звісно, здобуття познанськими єзуїтами освіти за кордоном. Це дозволило не лише отримати недоступні у тодішній Польщі знання і вкрай цінний як для того часу досвід, але й зумовило послідовне створення в столиці Великопольщі наукового осередку європейського рівня. Отже, навчання і подорожі більше не відігравали роль лише чинників освічення певного індивіду, але були насамперед важливим елементом реформування Познанського колегіуму. Останнє здійснювалося зусиллями цілої групи осіб, пов'язаних із цим осередком ордену (професорів, випускників, меценатів i, зрозуміло, самих учнів), які в черговий раз спробували - цього разу завдяки високому науковому рівню - звільнитися від пут, котрими зв'язала їх недружня Краківська академія ${ }^{7}$. Саме тому кожен познанський єзуїт, перебуваючи за кордоном, приділяв чимало уваги вивченню не лише точних наук, але й нових методів їх викладання; спостерігав за діяльністю лабораторій і обсерваторій, аби згодом відтворити їх у власному колегіумі; відвідував лекції і читав праці професорів, аби наслідувати їм після повернення на Батьківщину. Водночас він нав'язував тісну співпрацю із астрономами і фізиками, а також встановлював контакти з меценатами науки. Зрештою він був мандрівником, який просто цікавився усіма новинками.

Освіта і діяльність Юзефа Рогалінського (1728-1802рр. $)^{8}$ - найвидатнішого 3 познанських єзуїтів, котрі займалися наукою - чудово ілюструє це прагнення до здобуття знань і досконале вміння їх використовувати. Фізику і астрономію майбутній директор Познанського наукового осередку опановував у Парижі. На жаль, нам не відомо, хто саме 3 місцевих професорів навчав його цим предметам. Але в тодішній Європі чи не найбільшою славою користувалися саме керівники паризьких фізичних кабінетів і обсерваторій: Жозеф Ніколя Деліль, Ніколя Луї де Лакайль, Жозеф Жером Лефрансуа де Лаланд, П’єр Шарль Лемоньє, Жан-Антуан Нолле. Усі вони фактично стояли біля витоків астрономії і фізики доби Просвітництва. Розглянемо однак для прикладу впливи, зумовлені контактами Рогалінського із не менш відомим і видатним астрономом Александром Гуа Пінгре (1711-1796 pp. $)^{9}$ - директором обсерваторії абатства св. Женев’ єви. Рогалінський познайомився із Пінгре під час навчання у Парижі. Французький астроном спеціалізувався на проблемі часу. Він опублікував трактат про стан неба в 1754-1757 pp., а також написав працю про спосіб верифікації дат. Впливи наукових інтересів Пінгре досить легко простежуються в ранній астрономічній діяльності Рогалінського. Одразу ж після повернення 3 Франції той видав свій трактат під назвою «Назавжди вирахувана таблиия сходу й заходу сония для Познані і прилеглих місиевостей» ${ }^{10}$. Тривалий час директор познанської обсерваторії листувався і співпрацював з Пінгре, повідомляючи йому про свої спостереження. Цей осередок астрономії посів гідне місце в європейській науці: про його значущу роль можна дізнатися зі статті того ж Александра Гуа Пінгре, в якій узагальнюються результати міжнародних спостережень за затемненням сонця, яке відбулося 1 квітня 1764 р. В цій розвідці, опублікованій 1766 р., подається розлога замітка про докладні вимірювання географічної широти, які були проведені у Познані “надзвичайно досвідченим спостерігачем"

Отримавши необхідний досвід і солідні знання, Рогалінський - разом із багажем надзвичайно цінних фізичних і астрономічних інструментів ${ }^{12}-1762$ р. повертається до Познані. Таким чином, він став останнім з семи великопольських єзуїтів, котрі вивчали точні науки за кордоном. Майже тринадцятирічний період набуття познаньцями освіти в європейських школах доби Просвітництва був надзвичайно плідним: у наступному десятилітті 
місцевий єзуїтський колегіум став найкращим у царині точних наук в Короні і гідно конкурував з Віленською академією. Непересічний характер познанського освітнього осередку, втім, був пов'язаний не лише із блискучою освітою професорів. Адже дійсною ознакою його величі стало створення та облаштування фізико-математичного кабінету і астрономічної обсерваторії.

Осередок точних наук у Познані створив 1759 р. Ігнацій Хмєлєвський (1726-1764рp. $)^{13}$, який якраз повернувся з навчання у Марселі, де набував знання під керівництвом славетного астронома, математика і гідрографа Еспріта Пезена (1692-1776 рр.) . $^{14}$. Хмєлєвський обійняв тоді - як перший постійний професор - кафедру математики і заснував лабораторію. Остання, відповідно до освітньої моделі доби Просвітництва, мала стати запорукою читання оновленого курсу фізики ${ }^{15}$. Він зрештою також був започаткований Хмєлєвським. I вже в 1761 р. для одного 3 перших його учнів - Яна Папроцького (1738-1784 pp. $)^{16}$ створили другу в колегіумі кафедру математики. Згодом Хмєлєвський і Папроцький виконували функцію асистентів Рогалінського в заснованій ним обсерваторії, де він був директором. Розбудова і оснащення наукових інститутів стали можливими насамперед завдяки щедрій допомозі королеви Франції Марії Лещинської, яка подарувала познанським єзуїтам багато цінних книжок, кілька десятків тисяч франків та чимало астрономічних і фізичних інструментів.

Отже, познанський осередок точних наук постав завдяки сумам, які походили з гаманця дружини Людовіка XV. А його діяльність грунтувалася на тому багажі знань, котрі місцеві професори здобули за кордоном (i, насамперед, у Франціï). Тому не дивно, що цей храм науки було організовано і оснащено на французький манер. В Познанському колегіумі був великий математично-фізичний кабінет, який складався з трьох приміщень $i$ був упорядкований відповідно до європейських норм ${ }^{17}$. На даху будівлі, ще до приїзду Рогалінського, збудували вежу, котра слугувала астрономічною обсерваторією ${ }^{18}$. Цей осередок ордену також мав надзвичайно богату бібліотеку. 3 точки зору оснащення його наукові інститути, всупереч багатьом пізнішим оцінкам ${ }^{19}$, не мали собі рівних у тодішній Польщі. Скажімо, математично-фізичний кабінет взагалі став першим подібним закладом на теренах Речі Посполитої. Своєю чергою астрономічна обсерваторія, хоча й з'явилася через дев'ять років після віленської, на разі перевищувала іiі за розмаїттям приладів і науковим рівнем проведення спостережень.

Завдяки сучасному оснащенню астрономічної обсерваторії Рогалінський міг проводити у Познані спостереження і вимірювання, які були рідкісними для тодішньої Польщі за своєю точністю ${ }^{20}$. Більшість астрономічних інструментів походила з Франції і була витвором найвидатніших фахівців, причому деякі з них сконструйовані саме на спеціальне замовлення єзуїтів. Серед понад десяти астрономічних інструментів ${ }^{21}$ в Познані були наступні: квадрант з мікрометром, паралактична зорова труба і астролябія з осередку відомого Каніве 22 ; донині працюючий астрономічний годинник Лепота 23 ; армілярна сфера, зроблена в 1762 р. Мартінем ${ }^{24}$ у Версалі; i, нарешті, надзвичайно цінний годинник Бушера, який вимірює хвилини і секунди.

Період розквіту познанського наукового осередку доби Просвітництва припадає на проміжок часу між поверненням єзуїтів із закордонних студій і остаточною ліквідацією ордену в Польщі. Чималі фінансові видатки, величезні організаційні зусилля і насамперед високий інтелектуальний рівень викладачів - все це й зумовило появу модерного закладу, який сягнув вершин тодішньої європейської науки. Міжнародну значущість познанської обсерваторії можна прослідити у багатьох площинах. Надзвичайно цікавим є вкрай заплутане і майже не досліджене питання взаємовідносин між рухом, відомим під назвою Доба Розуму, і реформою, яку репрезентували єзуїти - у рамках спільного для обох цих течій Просвітництва. Відомий „розумовий переворот” у сфері точних наук був здійснений на познанському грунті насамперед зусиллями єзуїтів, які повернулися з Франції 25 і прищепили в Польщі філософію recentiorum. Але вона в їх інтерпретації набула своєрідного характеру, оскільки зважала на теологічні бар'єри ${ }^{26}$. Роль познанської астрономії в цьому специфічному (єзуїтському!) річищі Просвітництва набуває в даному контексті цілком нового значення. Наслідування французьких метрів їх познанськими адептами могло забезпечити подальшу діяльність єзуїтів Франції (а тут їх подальша доля виглядала 
вкрай непевною) в Речі Посполитій, де позиції ордену здавалися непорушними. Єзуїти Великопольщі, завдяки своїй освіті і нав'язаним у Франції контактам, мали стати немов апостолами ідеології, затаврованої державою Людовіка XV. Таким чином, познанський науковий осередок став по суті посмертним творінням французьких єзуїтів-професорів, а згадане специфічне єзуїтське Просвітництво розквітло і ще кілька років продовжувалося у Познані.

Ще одним свідченням важливого міжнародного значення астрономічної обсерваторії в Познані є жвавий інтерес до ії діяльності з боку іноземних вчених. Його безпосереднім наслідком стало поширення доброї думки про цей заклад за кордоном. Першою ознакою появи подібного інтересу стала праця в познанській обсерваторії двох єзуїтів із Франції Жана де Лаборда (1730-1777 рр.) і Антуана Луї Сіонеста (1742-1820 рр.). Вони прибули до Польщі разом із цілою групою своїх співбратів, яких було вигнано з їхньої Батьківщини. Ці особи відіграли важливу роль у піднесенні наукового осередку в Познані - як 3 технічної, так і з інтелектуальної точки зору. Жан де Лаборд раніше викладав експериментальну фізику у знаменитому Колегіумі Генріха IV в Ла Флеш. У Познані він працював асистентом Рогалінського в обсерваторії ${ }^{27}$; опублікував спостереження, зроблені під час затемнення сонця в 1764 p. $^{28}$, i навіть займався конструюванням астрономічних інструментів. Щодо Сіонеста, то він був ще сильніше пов'язаний із головним містом Великопольщі. Окрім того, цього єзуїта певною мірою можна вважати інтелектуально спорідненим із Юзефом Рогалінським, оскільки вони обидва були учнями відомого Нолле ${ }^{29}$. Сіонест працював разом з Рогалінським в обсерваторії, беручи участь в т.ч. у спостереженнях за затемненням Сонця і Полярною зіркою в $1764 \mathrm{p.}^{30}$.

Слід також зазначити, що познанський математично-фізичний кабінет і обсерваторію відвідали кілька мандрівників, які проїжджали через столицю Великопольщі. Серед них були й два світочі точних наук - математики і астрономи Леонард Ейлер (1707-1783 pp.) (1) $^{31}$ і Йоганн III Бернуллі (1744-1807рр.) $)^{32}$. Ці найкращі громадяни „республіки наук” доби Просвітництва залишили спомини, які доводять важливе значення познанської обсерваторії. Леонард Ейлер, оцінюючи в 1766 р. наявні там інструменти, зазначив, що навіть не сподівався побачити настільки багаті колекції в Познані ${ }^{33}$. Власне саме після цього візиту Рогалінський - як надзвичайно талановитий астроном - став користуватися повагою Ейлера. Останній навіть десятиліттям пізніше, у 1776 р., $з$ великою пошаною висловлювався про познанського науковця, вважаючи його спостереження найточнішими у Польщі ${ }^{34}$. Через дванадцять років після Ейлера через Познань проїжджав Йоганн III Бернуллі. У своїй реляції про подорож Польщею, яка дійшла донині ${ }^{35}$, він охарактеризував тодішній стан знаменитого нещодавно наукового осередку. 3 цього джерела довідуємося про те, наскільки масштабними були руйнування і пограбування, яких зазнала обсерваторія після ліквідації ордену ${ }^{36}$.

Наприкінці нашої розвідки варто зрештою звернути увагу на те, що в історіографії несправедливо недооцінюється наукове значення осередку точних наук, який виникає у XVIII ст. при єзуїтському колегіумі у Познані ${ }^{37}$. На нашу думку, провину за це несуть в т.ч. знамениті слухачі лекцій Рогалінського. I, насамперед, йдеться про Яна Шнядецького, який отримав або точніше вивіз більшість інструментів з познанського осередку і обсерваторії, аби оснастити ними нову обсерваторію краківської Коронної головної школи. Як зазначалося вище, астрономічні прилади з Великопольщі, всупереч свідченням Шнядецького і їх численним рецепціям в історіографії, тривалий час були найціннішим устаткуванням збудованого ним обійстя Уранії в Кракові.

Обсерваторія і математично-фізичний кабінет в Познані, які були створені наприкінці Саксонської доби, динамічно працювали і мали найкраще для того часу оснащення. Цей науковий осередок перевищив інші подібні заклади в Речі Посполитій і природно посів гідне місце в світовій науці. Але він зрештою - під гаслом проведення реформи - був закритий, пограбований і знищений ${ }^{38}$ владою Краківської академії, яка діяла за посередництва Комісії Едукації Народової ${ }^{39}$. 
${ }^{1}$ Познанському осередку точних наук XVIII ст. приділяється небагато уваги в історіографії. Детально про нього писали лише Францішек Хлаповський (в біографічному нарисі Юзефа Рогалінського, підготовленому до 100-ї річниці його смерті) і Станіслав Беднарський (в монографії 3 історії єзуїтських шкіл у другій половині XVIII ст.). Chłapowski F. Życie i prace księdza Józefa Rogalińskiego. Cz. I // Roczniki Towarzystwa Przyjaciół Nauk Poznańskiego. T. XXVIII. 1902. S. 115-185; Cz. II. // Roczniki Towarzystwa Przyjaciół Nauk Poznańskiego. T. XXXI. 1905. S. 27-117; Bednarski S. Upadek i odrodzenie szkół jezuickich w Polsce. Kraków, 1933. S. 359-369. Див. також: Forycki M. Kontakty astronomii i fizyki poznańskiej z Francją w dobie Oświecenia // Kronika Miasta Poznania. T. III. 1997. S. 207-224.

23 познанським обійстям Уранії можна порівняти лише обсерваторію, яку створив у Віленській академії Томаш Жебровський (1753 р.). Однак у період розквіту астрономічного осередку в Познані (1762-1764 рр.) литовська обсерваторія переживала кризу. Вона все ще залишалася вкрай бідною на інструменти й прилади, а насамперед - в ній була вакантною посада спостерігача. Див.: Łukaszewicz J. Historia szkół w Koronie i Wielkim Księstwie Litewskim od najdawniejszych czasów aż do roku 1794. T. IV. Poznań, 1851. S. 45--46; Bednarski S. Op. cit. S. 340-353.

${ }^{3}$ У фізичному кабінеті, який називали тusaeum mathematico-physicum, було кілька десятків унікальних оптичних, гідравлічних, механічних і електричних інструментів, переважну більшість яких мали закордонне походження. Там можна було також знайти численні цікавинки: скам'янілості, індіанські пам'ятки, китайські тексти еtc. Див.: Rogaliński J. Doświadczenia skutków rzeczy pod zmysły podpadających na publicznych posiedzeniach w Szkołach Poznańskich Societatis Jesu na widok wystawiane i wykładane. T. IV. Poznań, 1765. S. 451; Bednarski S. Op. cit. S. 360.

${ }^{4}$ Пop.: Kucharzewski F. O astronomii w Polsce, materiały do dziejów tej nauki w naszym kraju // Pamiętnik Towarzystwa Nauk Ścisłych w Paryżu. T. II. Paryż, 1872. S. 163; Maugras S. G. Dernières années du Roi Stanislas. Paris, 1906. S. 339 in.; Gołębiowski S. Rola i znaczenie kolegium Lubrańskiego i kolegium Jezuickiego w XVI, XVII i XVIII w. dla Wielkopolski // Przegląd Wielkopolski. R. 1947. Nr 1-3. S. 13.

${ }^{5}$ Bednarski S. Op. cit. S. 58.

${ }^{6}$ Пор.: Pniewski W. Akademia Poznańska. Szkic historyczny. Poznań, 1919. S. 10.

${ }^{7}$ Пор.: Załęski S. Jezuici w Polsce. T. IV. Cz. I. Kraków, 1905. S. 155. Про конфлікт між Краківською академією і Познанським єзуїтським колегіумом стисло пише С. Голембьовський: Gotębiowski S. Op. cit. S. 10-13.

${ }^{8}$ Найповнішу біографію Юзефа Рогалінського подає Ф. Хлаповський: Chtapowski F. Op. cit. Див. також: Brown J. Biblioteka pisarzów assystencyi polskiej Towarzystwa Jezusowego. Poznań, 1862. S. 341-342; Dmochowski F. X. Wiadomości o życiu i pismach Józefa Rogalińskiego // Ejusdem. Pisma rozmaite. Cz. I. Warszawa, 1826. S. 218; Estreicher K. Bibliografia polska. T. XXVI. S. 334-335; Polski Słownik Biograficzny. T. XXXI. S. 401-404; Nowy Korbut. T. VI. S. 123-125; Historia Nauki Polskiej. T. VI. S. 568-569.

${ }^{9}$ Див.: Grand Dictionnaire Universel du XIXe siècle. Paris, 1866-1890. T. XII. S. 1036.

10 Rogaliński J. Tablica na zawsze wyrachowana wschodu i zachodu słońca na Poznań i miejsca przyległe. Poznań, 1763.

11 Див.: Chtapowski F. Op. cit. Cz. I. S. 174.

${ }^{12}$ Uniwersytet Poznański za rektoratu Heliodora Święcickiego. Księga Pamiątkowa / pod red. A. Wrzoska. Poznań, 1924. S. 18.

${ }^{13}$ Про Ігнація Хмєлєвського, який через передчасну смерть $є$ маловідомою постаттю, подає трохи інформації С. Беднарський: Bednarski S. Op. cit. S. 359.

${ }^{14}$ Grand Dictionnaire... T. XII. S. 741.

${ }^{15}$ Nollet J. A. Leçons de physique expérimentale. T. I. Paris, 1749. S. IX in.

${ }^{16}$ Див.: Poplatek J. Komisja Edukacji Narodowej. Udział byłych jezuitów w pracach KEN. Kraków, 1973. S. 202; Bednarski S. Op. cit. S. 368.

${ }_{17}^{17}$ Sigaud de La Fond J.-A. Description et usage d'un cabinet de physique. Paris, 1775.

${ }^{18}$ Вежу спорудили саме на даху колегіуму, а не окремому фундаменті. Це негативно впливало на проведення спостережень. Пор.: Kucharzewski F. Op. cit. S. 169.

${ }^{19}$ Несправедливу оцінку познанській колекції дає вже Ян Щнядецький: „я знайшов цей кабінет, занадто оспіваний і дорого оцінений [...], в деяких грубий механізм, який не відповідає вимогам тодішньої фізики”. Див.: Jana Śniadeckiego życie, przez niego samego opisane // Korespondencja Jana Śniadeckiego. Listy z Krakowa / pod red. L. Kamykowskiego. T. I. Kraków, 1932. S. 29.

${ }^{20}$ Пор.: Chłapowski F. Op. cit. Cz. II. S. 173-182.

${ }^{21}$ Про оснащення познанської обсерваторії можна дізнатися зі звітів осередків, котрі отримали або успадкували його інструменти. Пор.: Karliński F. Rys dziejów obserwatorium astronomicznego Uniwersytetu Krakowskiego // Zakłady Uniwersyteckie w Krakowie. Kraków, 1864. S. 96-97, 107; Jana Śniadeckiego życie... S. 29-30; Pagaczewski J. Astronomiczne instrumentarium Jana Śniadeckiego // Urania. T. VIII. 1956. S. 229-231; Witkowski J. Astronomia // Nauka w Wielkopolsce / pod red. G. Labudy. Poznań, 1973. S. 1082. 
22 Жак Каніве (1721-1774 рр.) в 1751 р. був призначений конструктором інструментів Паризької академії наук, завдяки чому став першим виробником астрономічних приладів на континенті. Пор.: Daumas M. Les instruments scientifiques aux XVIIe et XVIIIe siècles. Paris, 1953. S. 137-138, 230.

23 Жан Андре Лепот (1720-1787 pр.) - французький годинникар.

24 Про Мартіна маємо надзвичайно бідні відомості. Будучи одним із небагатьох французьких конструкторів, він працював поза Парижем (а саме - у Версалі). Ця обставина дозволяє припустити, що познанські єзуїти нав'язали із ним контакти через королівський двір. Пор.: Daumas M. Op. cit. S. 346.

${ }^{25}$ Пop.: Smoleński W. Przewrót umysłowy w Polsce wieku XVIII. Warszawa, 1979. S. 92.

${ }^{26}$ Fabre J. Stanislas-Auguste Poniatowski et l'Europe des Lumières. Paris, 1952. S. 75-79.

${ }^{27}$ Smoleński W. Op. cit. S. 121-122.

28 Див.: Bednarski S. Op. cit. S. 492.

29 Жан Антуан Нолле (1700-1770рр.) - видатний французький фізик, член Паризької академії наук, автор двох фундаментальних підручників: Leçons de physique expérimentale. Paris, 1743; L'art des expériences. Amsterdam, 1770. Пор.: Grand Dictionnaire... T. XI. S. 1061; Stasiewicz I. Poglądy na naukę w Polsce okresu Oświecenia na tle ogólnoeuropejskim // Monografie z Dziejów Nauki i Techniki. T. XXXVIII. Wrocław, 1967. S. 99, 127. Нолле став відомий в т.ч. завдяки публічним дослідам, курсам і демонстраціям, які він здійснював в Парижі і Версалю. Рогалінський, чудовий популяризатор знань, згодом наслідував його, відкриваючи двері музею для познанської громадськості і публічно демонструючи, як функціонують його прилади. Див.: Łakomy L. Udział duchowieństwa katolickiego w rozwoju nauk matematyczno-przyrodniczych w Polsce // Przegląd Powszechny. T. CXCV. Kraków, 1932. S. 304

${ }^{30}$ Про це згадує Александр Гуа Пінгре у вищезгаданій своїй статті. Див.: Chłapowski F. Op. cit. Cz. I. S. 174; Smoleński W. Op. cit. S. 121-122.

31 Леонард Ейлер - математик і астроном, з 1727 р. був членом і співробітником Петербурзької академії наук, перебував у складі Берлінської академії (1741-1766 рр.). Повертаючись звідти до Росії, він проїжджав і зупинявся у Познані. Див.: Encyclopaedia Universalis. T. VII. Paris, 1985. S. 525-526; Dunajówna M. Z dziejów toruńskiego czasopisma „Thornische Wöchentliche Nachrichten und Anzeigen” (1760-1772). Toruń, 1960. S. 115.

${ }^{32}$ Про Бернуллі див.: Liske X. Cudzoziemcy w Polsce. Lwów, 1876. S. 200.

${ }^{33}$ Chtapowski F. Op. cit. Cz. I. S. 128; Bednarski S. Upadek i odrodzenie... S. 360.

34 Див.: Kłado T., Wołoszyński R. W. Korespondencja Stanisława Augusta z Leonhardem Eulerem i Petersburską Akademią Nauk 1766-1783 // Studia i Materiały z Dziejów Nauki Polskiej. Seria C. Zeszyt X. Warszawa, 1965. S. 21.

${ }_{35}$ Щоденники тієї подорожі були перекладені польською: Polska stanisławowska w oczach cudzoziemców. T. I / oprac. W. Zawadzki. Warszawa, 1963.

${ }^{36}$ Ibidem. S. 459-460.

${ }^{37}$ Про існування і діяльність динамічного наукового середовища в Познані забули вже в XIX ст. Його не згадують навіть знамениті представники Великопольщі - Станіслав Козьмян (Koźmian S. O popularnych wykładach naukowych // Roczniki Towarzystwa Przyjaciół Nauk Poznańskiego. T. V. 1869. S. 86) і Кароль Лібельт, який змальовує історію астрономічних спостережень в давній Польщі (Libelt K. O zaćmieniu słońca w roku 1868 // Roczniki Towarzystwa Przyjaciół Nauk Poznańskiego. T. V. 1869. S. 337-351).

${ }^{38}$ Цікаву алюзію щодо занепаду єзуїтського наукового осередку в Познані містить анонімний рукопис тієї доби: „Одного дня сміливіше перо наших нащадків, коли звинувачення у безчесності вже не уражатимуть померлих, зможе описати той безлад, який тоді творився, лише ганьблячи нашу країну [...] місцева бібліотека, яка містила чимало книжок найкращих авторів, була спустошена, а математичні і фізичні прилади, зібрання яких в місцевому музеї не знало собі рівного в усій країні, повсюдно розпорошене". Цит. по: Eukaszewicz J. Obraz historyczno-statystyczny Miasta Poznania w dawniejszych czasach. T. II. Poznań, 1838. S. 25.

39 Див., зокрема: Komisja Edukacji Narodowej i jej szkoły w Koronie 1773-1794 / wydał T. Wierzbowski. Z. 38: Protokóły posiedzeń KEN 1778-1780. Warszawa, 1913. S. 184; Protokoły posiedzeń Komisji Edukacji Narodowej 1773-1785 / oprac. M. Mitera-Dobrowolska. Wrocław, 1973. S. 18, 37, 214, 365; Bandtkie J. S. Historya Biblioteki Uniwersytetu Jagiellońskiego w Krakowie. Kraków, 1821. S. 104, 126; Kołłataj H. Raporty o wizycie i reformie Akademii Krakowskiej / oprac. M. Chamcówna. Wrocław, 1967. S. 106, 133; Labuda G. Główne linie rozwoju nauki w Wielkopolsce (do r. 1919) // Nauka w Wielkopolsce... S. 24; Poplatek J. KEN. Udział byłych jezuitów... S. 40, 56. 